\title{
Illness-induced aversion learning in a desert species of rodent (Acomys cahirinus)
}

\author{
FRANK ETSCORN \\ George Peabody College for Teachers, Nashville, Tennessee 37203
}

\begin{abstract}
The spiny mouse (Acomys cahirinus) can learn an illness-induced aversion in one trial. After six sessions of baseline drinking, mice were made ill by a toxic injection of lithium chloride (US) 30 min after having drunk from a novel sucrose solution (CS). Two days later, the animals were tested for the presence of aversions by offering them a simultaneous choice of drinking either sucrose solution or plane water. The sucrose-drinking/illness-contingent animals demonstrated significant aversions to the sweet solution when compared to controls (sucrose-drinking/ saline-injected, sucrose-drinking/no-injection, plain-water-drinking/lithium chloride-injection, and plain-water-drinking/no-injection groups).
\end{abstract}

A rat will quickly learn to avoid consuming a distinctly flavored fluid if that fluid had previously been conditionally paired with a gastrointestinal malaise induced by poison injection or X-ray irradiation (Revusky \& Garcia, 1970). In Pavlovian terminology, the taste cue is the conditioned stimulus (CS) and the illness is the unconditioned stimulus (US). This basic illness-induced taste aversion exhibits a great interspecific generality. Aversions have been obtained in such diverse groups of animals as fish (MacKay, 1974), snakes (Burghardt, Wilcoxon, \& Czaplicki, 1973), birds (Brower, 1969; Wilcoxon, Dragoin, \& Kral, 1971; Wilcoxon, Etscorn, \& Czaplicki, Note 1), albino mice (Etscorn, 1973; Kimeldorf, Garcia, \& Rubadeau, 1960), rats (Garcia, Kimeldorf, \& Koelling, 1955), guinea pigs (Braveman, 1974), hamsters (Johnston \& Zahorik, 1975), cats (Kimeldorf, Garcia, \& Rubadeau, 1960), coyotes (Gustavson, Garcia, \& Rusiniak, 1974), cougars (Gustavson \& Garcia, 1974), and monkeys (Harlow, 1964; Johnson, Beaton, \& Hall, 1975; Revusky \& Gorry, 1973; Wilcoxon \& Etscorn, Note 2).

To date, however, illness-induced taste aversions in desert species of rodents have been relatively difficult to obtain experimentally, possibly because of the difficulty in inducing measurable quantities of water consumption. Abernathy (Note 3) unsuccessfully attempted to condition visually mediated aversions (tinted water) in gerbils with multiple conditioning trials; however, aversions were established with some difficulty to flavored water. Specifically, the gerbil is capable of metabolizing the water from relatively dry laboratory chow and is therefore almost independent

This article contains part of the data from a dissertation submitted to George Peabody College. Acknowledged with sincere thanks are Richard Porter and Hardy Wilcoxon, who directed the study. This research was supported by NICHD Grant 00973 . The author's present address: Department of Psychology, New Mexico Institute of Mining and Technology, Socorro, New Mexico 87801. of freely available water, virtually eliminating water as a CS vehicle. Likewise, physiological data supplied by the Hoeltge Animal Care Equipment Company indicate that if fresh feed such as carrots or lettuce is available to the gerbil, water per se is not required for its well-being. Prakash and Jain (1971) obtained baitshyness in two species of Indian gerbils (Tatera indica indica Hardwicke and Meriones hurrianae Jerdon) by lacing the animals' diet with toxic zinc phosphide. This treatment produced an aversion to the diet even when zinc phosphide was absent. As the study was applied in purpose, no attempt was made to control the quantities of poison consumed, the temporal relationships between ingestion of poison and the onset of illness, and the possibility that avoidance was due to sensitization rather than associative learning.

The major question in this study is whether the spiny mouse, a species indigenous to the desert regions of the Near East, is able to form an illness-induced aversion to a novel taste stimulus such as sucrose solution. As the spiny mouse is physiologically similar to the gerbil with respect to a reduced dependence on free water, the study also concerns whether the spiny mouse could be induced to drink measurable amounts of fluids.

\section{METHOD}

\section{Subjects}

For the experiment, 49 naive adult spiny mice of mixed sex were chosen at random from the laboratory breeding colony. Weights of the animals averaged $52 \mathrm{~g}(\mathrm{SD}=10.5)$. The subject species is a murid rodent indigenous to the arid Near East which is noted both for its highly precocial infants (Ewer, 1968; Ruch, 1967) and for its reduced dependence on freely available water.

\footnotetext{
Apparatus

All subjects were individually housed in suspended $25 \times 18 \times$ $18 \mathrm{~cm}$ high wire-mesh cages and fed Purina Mouse Chow ad lib for the duration of the study. All experimental procedures,
} 
except for weighing the animals and injecting them, were conducted while the mice were in their home cages. Temperature in the lab was maintained at $25^{\circ} \mathrm{C}\left( \pm 1^{\circ}\right)$ with evenly distributed overhead fluorescent lighting cycled on at $8 \mathrm{a} . \mathrm{m}$. and off at $6 \mathrm{p} . \mathrm{m}$. Sucrose solutions (CS) were prepared $(20 \%$, W/V) before each test session with distilled water. For every drinking session, all liquids were made available beginning at $8: 30$ a.m. via drinking tubes fashioned from calibrated 6-cc disposable syringes which had been fitted with $6.5-\mathrm{cm}(2.5 \mathrm{in}$.) stainless steel spouts (Wright \& Scheff, 1972). The illness-inducing agent (US) was a $20-\mathrm{ml} / \mathrm{kg}$ .15-molar solution of lithium chloride injected intraperitoneally with 1 1 $1 / 2$-in., 25-ga needles.

\section{Procedure}

In Session 1, all mice were deprived of their ad-lib tap water and randomly assigned to five nearly equal groups. On the following day, each subject was given access to two drinking tubes simultaneously affixed to the cage fronts (the spouts were approximately $3 \mathrm{~cm}$ apart). One of the tubes was filled with unflavored distilled water and the other was empty. After $10 \mathrm{~min}$ of drinking time, the tubes were removed and the amounts consumed were determined and recorded. Baseline drinking sessions continued in this manner, with the animals being watered every other day (due to this species' small need of freely available water) until a total of six measures were taken (Sessions 2-7). The placement of the full and empty tube for all animals was counterbalanced (RLLRRL) across days to negate any initial position preferences for any particular side of the cage. After Session 7, each subject was weighed to compute injection doses. On conditioning day (Session 8), Groups 1, 2, and 4 each received the CS (sweet water) in both drinking tubes for $10 \mathrm{~min}$. Groups 3 and 5 each had 10-min access to unflavored distilled water in two tubes. Thirty minutes following removal of the drinking tubes for all animals, Groups 1 and 3 were made ill by an injection of lithium chloride (US) while Group 2 received an equivalent-by-weight intraperitoneal injection of normal saline solution. Groups 4 and 5 were noninjected controls and were handled instead of being injected. The five groups and their respective treatments are depicted in Table 1.

As a no-water deprivation day was interposed between conditioning day and the first test day, no recuperation watering session was included. Session 9 (Test 1) consisted of simultaneously presenting all subjects with the choice of drinking for $10 \mathrm{~min}$ from a tube containing the CS or from one containing unflavored distilled water. For Test 1 , the CS was on the right side of the cage (relative to the experimenter), while for Test 2 (Session 10), the positions of the drinking tubes were reversed for each animal.

\section{RESULTS AND DISCUSSION}

Prior to analysis, preference indices were computed for each animal on each test day using the following

Table 1

Summary of Procedures and Results

\begin{tabular}{|c|c|c|c|c|}
\hline Groups & $\mathrm{N}$ & Treatment & $\begin{array}{r}\text { Suct } \\
\text { Prefer } \\
\text { Test } 1 \\
\end{array}$ & $\begin{array}{l}\text { ose } \\
\text { ences } \\
\text { Test } 2\end{array}$ \\
\hline 1. Sweet-Aversion & 10 & $\begin{array}{l}\text { Sweet Water, } \\
\text { LiCl Injection }\end{array}$ & 6 & 11 \\
\hline 2. Sweet-Baseline A & 10 & $\begin{array}{l}\text { Sweet Water, } \\
\text { Saline Injection }\end{array}$ & 62 & 76 \\
\hline 3. Sensitization & 10 & $\begin{array}{l}\text { Plain Water, } \\
\text { LiCl Injection }\end{array}$ & 42 & 73 \\
\hline 4. Sweet-Baseline B & 10 & $\begin{array}{l}\text { Sweet Water, } \\
\text { No Injection }\end{array}$ & 71 & 80 \\
\hline 5. $\mathrm{H}_{2} \mathrm{O}$-Baseline & 9 & $\begin{array}{l}\text { Plain Water } \\
\text { No Injection }\end{array}$ & 60 & 73 \\
\hline
\end{tabular}

formula: Amount of sweet water (CS) consumed/ amount of CS consumed + amount of plain water consumed $\times 100$. In this case, for example, an index of 75 would be indicative of a preference and 25 a rejection of the CS, while 50 would be demonstrative of an equal preference for the two liquids. Table 1 shows the mean preference score for each treatment group on Test Days 1 and 2.

Using individual preference scores, separate ANOVAs were computed across groups for each test day. Analysis of Test Day 1 data revealed a highly significant overall effect $(F=18.64 ; \mathrm{df}=4,44$; $\mathrm{p}<.001$ ), while further analysis, using Duncan's multiple range test for multiple comparisons between groups, indicated that Group 1 (CS-US) differed $(p<.001)$ from the four control groups. Moreover, the sensitization control group (plain water/LiCl injection) showed a significant difference from the plain-water/no-injection group (42 vs. 60 preference indices; $\mathrm{F}=4.93$, $\mathrm{df}=1,17 ; \mathrm{p}<.05)$, suggesting a sensitization effect. On conditioning day, these two groups (plain-water/LiCl-injection vs. plainwater/no-injection) did not differ with respect to the amounts of plain water consumed $(F=.08$; $\mathrm{df}=1,17)$. Similarly, there was no difference $(\mathrm{F}=1.03 ; \mathrm{df}=1,47)$ in liquid consumption between animals drinking sweet water on conditioning day (Groups 1, 2, and 4) and those having access to plain water (Groups 3 and 5). Test Day 2 likewise showed a highly significant overall effect $(F=14.64$; $d f=$ $4,44 ; \mathrm{p}<.001)$. A Duncan's multiple range test again revealed a significant difference $(p<.001)$ between the sweet-water/LiCl-injected group and the four control groups; however, there was no difference in the preferences evidenced by the plain-water $/ \mathrm{LiCl}$ injection group (sensitization control) and the plainwater/no-injection group (73 vs. 73 preference indices, respectively). Finally, individual ANOVAs were computed across groups on the amount of water consumed on the last adaptation day $(\overline{\mathrm{X}}=3.6 \mathrm{ml})$, on the amount of fluids consumed on conditioning day $(\overline{\mathrm{X}}=3.3 \mathrm{ml})$, and on subject weights obtained following Session $7(\bar{X}=54 \mathrm{~g})$. In each case, there was no reliable difference ( $\mathrm{F}<1$ for all three comparisons).

From the foregoing, it can be concluded that the spiny mouse is capable of learning an illness-induced aversion to sucrose solution following one conditional pairing of the sweet liquid and lithium-induced illness.

\section{REFERENCE NOTES}

1. Wilcoxon, H. C., Etscorn, F., \& Czaplicki, J. Illness-induced aversion based on visual cues from the environment. Paper presented at the Psychonomic Society, Denver, November 1975.

2. Wilcoxon, H. C., \& Etscorn, F. Failure to demonstrate illnessinduced aversions to visual cues in rhesus monkeys. Paper presented at the Southeastern Psychological Association, New Orleans, 1976. 
3. Abernathy, W. B. The utilization of visual and gustatory cues by the gerbil in an illness-induced aversion. Paper presented at the meeting of the Psychonomic Society, San Antonio, November 1970.

\section{REFERENCES}

Braveman, N. S. Poison-based avoidance learning with flavored or colored water in guinea pigs. Learning and Motivation, 1974, 5, 182-194.

Brower, L. P. Ecological chemistry. Scientific American, 1969, 220, 22-29.

Burghardt, G. M., Wilcoxon, H. C., \& Czaplicki, J. A. Conditioning in garter snakes: Aversion to palatable prey induced by delayed illness. Animal Learning \& Behavior, 1973, 1, 317-320.

ETSCORN, F. Effects of a preferred vs a nonpreferred CS in the establishment of a taste aversion. Physiological Psychology, 1973, 1. 5-6.

Ewer, R. F. Ethology of mammals. London: Logos Press, 1968.

Garcia, J., Kimeldorf, D. J., \& Koelling, R. A. Conditioned aversion to saccharin resulting from exposure to gamma radiation. Science, 1955, 122, 157-158.

Gustavson, C. R., \& Garcia, J. Aversive conditioning: Pulling a gag on the wily coyote. Psychology Today, 1974, 8, 60-72.

Gustavson, C. R., Garcia, J., \& Rusiniak, K. W. Coyote predation control by aversive conditioning. Science, 1974, 184, 581-583.

HARLOW, H. F. Effects of radiation on the central nervous system and on behavior-general survey. In T. J. Haley \& R. S. Snider (Eds.). Response of the nervous system to ionizing radiation: Second international symposium. Boston: Little, Brown, 1964. Pp. 627-644.

Johnson, C., Beaton, R., \& Hall, K. Poison-induced avoidance learning in nonhuman primates: Use of visual cues. Physiology and Behavior, 1975, 14, 403-407.

Johnston, R. E., \& ZAHoRIK, D. M. Taste aversions to sexual attractants. Science, 1975, 189, 893-894.

Kimeldorf, D. J., Garcia, J., \& Rubadeau, D. O. Radiationinduced conditioned avoidance behavior in rats, mice and cats. Radiation Research, 1960, 12, 710-718.

MACKAY, B. Conditioned food aversion produced by toxicosis in Atlantic cod. Behavioral Biology, 1974, 12, 347-355.

Prakash, I., \& JAIN, A. P. Bait shyness of two gerbils, Tatera Tatera indica indica Hardwicke and Meriones hurrianae Jerdon. Annals of Applied Biology, 1971, 69, 169-172.

REVUSKY, S. H., \& GARCIA, J. Learned associations over long delays. In G. Brower (Ed.), The psychology of learning and motivarion: Advances in research and theory (Vol. 4). New York: Academic Press, 1970. Pp. 1-84.

RevUsKy, S. H., \& GoRRY, T. Flavor aversions produced by contingent drug injection: Relative effectiveness of apomorphine, emetine, and lithium. Behavior Research and Therapy, 1973, 11, 403-409.

Ruch, W. Die Implantationseit und deren Beeinflussung durch die Laktation bei Acomys cahirinus dimidiatus. Revue Suisse Zoologie, 1967, 74, 566-569.

Wilcoxon, H. C., Dragoin, W. B., \& Kral, P. A. Illnessinduced aversions in rat and quail: Relative salience of visual and gustatory cues. Science, 1971, 171, 826-828.

Wright, D. C., \& Scheff, S. W. Inexpensive metabolism cages and drinking tubes. Behavior Research Methods \& Instrumentation, 1972, 4, 279-280.

(Received for publication February 14, 1977; accepted June 9, 1977.) 